\title{
Endophthalmitis prevalence in an university hospital
}

\section{Prevalência de endoftalmite em um hospital universitário}

\author{
Letícia Maria Coelho ${ }^{1}$, Thaís Martins de Souza ${ }^{1}$, Marco Antônio Guarino Tanure
}

\begin{abstract}
Purpose: To study endophthalmitis prevalence in an university hospital, assessing its epidemiological characteristics, symptoms onset, treatment and clinical outcome. Methods: We retrospectively reviewed medical records of patients diagnosed with endophthalmitis, from january 2009 to june 2011, identifying patient epidemiological characteristics, endophthalmitis cause, onset of symptoms time, previous treatment, hospital stay, treatment, culture results, clinical outcome and final visual acuity. Results: Sixtyeight patients, 44 women and 24 men, with a mean age of 56,99 years, were evaluated. Most were referred from other services $(27,94 \%)$, had already undergone to any medical treatment and/or surgery $(45,59 \%)$, presented some comorbidity $(60,29 \%)$ and resulted from trauma $(35,29 \%)$ or post-surgery $(22,06 \%)$. The average duration of onset of symptoms was 5,76 days and of hospitalization was 12,40 days. Initial and final visual acuity were both equal to or worse than light perception in $64,71 \%$ of cases. Most of patients $(58,82 \%)$ undergone to clinical treatment only and $69,12 \%$ of cases presented no results in culture. Conclusion: Endophthalmitis is one of the most serious and worst functional outcome between ophthalmologic disorders. Its rapid and accurate diagnosis is essential for appropriate and early treatment, in order to improve patient visual prognosis, ensuring better quality of life and socioeconomic reintegration.
\end{abstract}

Keywords: Endophthalmitis; Eye Infections; Epidemiology; Prevention and Control; Vision Disorders

\section{RESUMO}

Objetivo: Estudo da prevalência de endoftalmite em um hospital universitário, avaliando características epidemiológicas, tempo de sintomas, tratamento realizado e evolução clínica. Métodos: Avaliação retrospectiva dos prontuários de pacientes com diagnóstico de endoftalmite, no período de janeiro de 2009 a junho de 2011, quanto às características epidemiológicas do paciente, causa da endoftalmite, tempo de início dos sintomas, tratamento prévio, tempo de internação, tratamento realizado, resultados de culturas, evolução clínica e acuidade visual final. Resultados: Sessenta e oito pacientes, sendo 44 mulheres e 24 homens, com idade média de 56,99 anos, foram avaliados. A maioria foi referenciada de outro serviço (27,94\%), já tinha sido submetida a algum tratamento clínico elou cirúrgico $(45,59 \%)$ e possuía alguma comorbidade (60,29\%) que decorreu de trauma (35,29\%) ou pós-cirurgia (22,06\%). O tempo médio de início dos sintomas foi de 5,76 dias e o de internação de 12,40 dias. A acuidade visual inicial e a final foram para ambas igual ou pior que percepção luminosa em $64,71 \%$ dos casos. A maior parte dos pacientes (58,82\%) foi submetida apenas a tratamento clínico e, em $69,12 \%$ dos casos, a cultura foi negativa ou não foi realizada. Conclusão: A endoftalmite é uma das complicações mais graves e de pior resultado funcional entre as afecções oftalmológicas. Seu diagnóstico rápido e correto é fundamental para um tratamento adequado e precoce, a fim de melhorar o prognóstico visual do paciente, garantindo sua qualidade de vida e posterior inserção socioeconômica.

Descritores: Endoftalmite; Infecções oculares; Epidemiologia; Prevenção e controle; Transtornos da visão

\footnotetext{
${ }^{1}$ Hospital São Geraldo, Hospital das Clínicas, Federal University of Minas Gerais, Minas Gerais, MG, Brasil.

Study conducted at Hospital São Geraldo, Hospital das Clinicas, Federal University of Minas Gerais, Minas Gerais, MG, Brazil.
}

The authors declare no conflicts of interest

Received for publication 03/05/2014 - Accepted for publication 08/06/2014 


\section{INTRODUCTION}

$\mathbf{E}$ ndophthalmitis is an inflammation of the intraocular tissues $^{1}$, and is one of the most serious complications and with worst functional outcome among ophthalmic diseases ${ }^{2}$. Although it is a rare condition, it is potentially destructive since it creates irreversible damage to the delicate photoreceptor layer of the retina, and even with proper intervention results in partial or complete loss of vision, or even of the eye in a few days ${ }^{3}$.

It can be classified as postoperative (acute, chronic or late presentation), post-traumatic or endogenous ${ }^{4}$.

The etiopathogenesis, clinical presentation and development are variable depending on the type of endophthalmitis and the causative microorganism. Generally, the patient has decreased vision, pain and inflammatory signs of the anterior and/or posterior segment of the eye associated with a history of surgery, trauma, or systemic and debilitating diseases such as diabetes, neoplasms or immunosuppression ${ }^{5}$.

As it is a devastating condition ${ }^{6}$, the rapid and accurate diagnosis is essential for a proper and early treatment, which is initially established empirically, until there are the culture results and the necessary adjustments ${ }^{2}$.

The present study aimed to study the prevalence of endophthalmitis in a university hospital, assessing the epidemiological characteristics of the patients, the onset time of symptoms, the treatment performed and the clinical development, comparing the final visual acuity to the visual acuity present on admission.

\section{Methods}

This work is a descriptive observational study of the universe of all patients admitted at Hospital São Geraldo, Hospital das Clinicas, Federal University of Minas Gerais with a diagnosis of endophthalmitis from January 2009 to June 2011.

The record books of the surgical services were analyzed in order to detect all patients who were diagnosed with endophthalmitis, the date and the procedure performed. From this information and the registration number, the medical records of every patient were assessed.

The epidemiological characteristics of each patient were studied, such as age, gender, profession, origin and presence of comorbidities. The cause of endophthalmitis, the time from onset of symptoms to consultation at the health service, prior treatment history and visual acuity at hospital admission were assessed. Then, hospitalization, the treatment performed, the results of microbiological cultures performed and the clinical development of the patient and their final visual acuity at hospital discharge were considered.

The project was submitted to the Ethics Committee of the Federal University of Minas Gerais (CAAE: 0534.0.203.000-11) and the authorities of the institution where the research was conducted answered the consent term to carry out the present work.

As it was an epidemiological study, patients were not identified and the institution where the research was conducted could decide on dropping out to participate. All provisions on Research Ethics were observed, according to the resolution 196/96.

The tabulation of the data obtained was done by the program Excell, and the statistical analysis by the statistical program SPSS 13.0 for Windows. To assess if there was any correlation between the time from onset of symptoms, age, initial visual acuity or time of hospitalization and the final visual acuity the Spearman's correlation test was employed. To compare the final visual acuity among the different groups of patients separated by culture, cause, prior treatment, comorbidities and treatment, the non-parametric test of Kruskal-Wallis was used.

\section{$\underline{\text { Results }}$}

68 patients were evaluated, of which 44 were male and 24 female, with a mean age of 56.99 years (7-88 years). Regarding the merits, $14.71 \%$ were already patients of the hospital, $27.94 \%$ were sent from another hospital, and $22.06 \%$ sought the health services on their own. Of all the patients, $42.65 \%$ had already undergone some type of medical treatment, and $2.94 \%$ to some surgical treatment. Regarding the presence of comorbidities, $29.41 \%$ of the patients had some systemic disease, $22.06 \%$ some ocular disease, and $8.82 \%$ some kind of immunodeficiency. Regarding the probable etiology, $10.29 \%$ were due to blebitis, $19.12 \%$ after cataract extraction, $2.94 \%$ post-penetrating keratoplasty, $35.29 \%$ post-trauma, $14.71 \%$ post-keratitis, $1.47 \%$ after removal of stitches, $11.76 \%$ were considered endogenous, and in $4.41 \%$, the cause has not been identified (Figure 1).

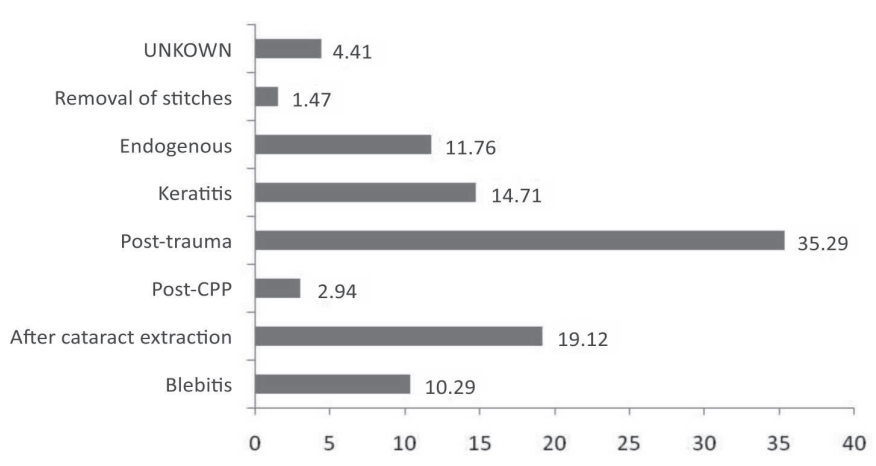

Figure 1. Distribution of patients (\%) according to the probable cause of endophthalmitis.

The mean time from onset of symptoms was 5.76 days (130 days), and the mean time of hospitalization was 12.40 days (235 days). Regarding initial visual acuity (VA), $26.47 \%$ of the patients had no light perception (LP), 38.24\% had LP, 30.88\% had VA less than or equal to $20 / 400$, and only $4.41 \%$ better than $20 / 400$. Regarding the final VA, $39.71 \%$ of the patients had no LP, $25.00 \%$ had LP, $29.41 \%$ had VA less than or equal to $20 / 400$, and only $5.88 \%$ better than $20 / 400$ (Figure 2).

Of all the patients, $58.82 \%$ underwent only clinical treatment, $19.12 \%$ to some kind of surgical treatment, and $22.06 \%$ progressed to evisceration. Regarding the microbiological results, gram-positive bacteria were identified in $19.12 \%$ of the cases, and gram-negative in $5.88 \%$ of them. In $1.47 \%$ of them there was mixed growth, and in $4.41 \%$ there was the growth of fungi. In $69.12 \%$ of the cases, the culture was negative or was not performed. There was no relation between the final VA and the time to seek the health service, nor between the final VA and the time of hospitalization. There was a weak positive correlation between the patient's age and the final VA, and a substantially positive correlation between the initial VA and the final VA. There was no significant difference in the final visual acuity among 
the different groups of patients, separated by culture, cause, prior treatment, comorbidities and treatment.

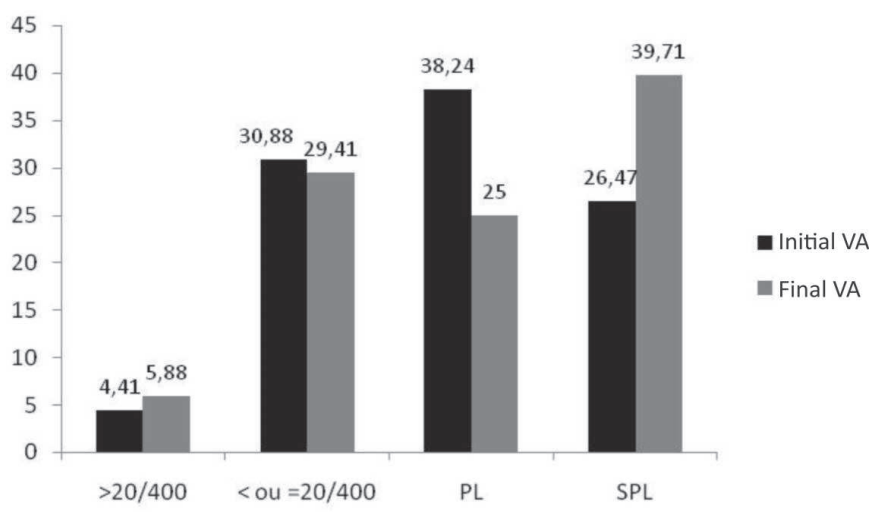

Figure 2. Distribuição of patients (\%) according to initial and final visual acuities.

\section{Discussion}

As in other studies ${ }^{2,7,8}$, there was a predominance of males among the patients, which may have resulted from the large number of cases of post-traumatic endophthalmitis, usually predisposed by the type of economic occupation of the patient, more common among men.

Regarding the cause, post-traumatic infections were more frequent than those following surgery, differing from most of the literature ${ }^{3,9,10}$. This can be explained by the large number of cases referred in the countryside of the state, especially from rural areas, related to severe trauma, which require care in more specialized hospitals like ours.

As in other work ${ }^{2}$, there was a great delay in seeking the health system, which might have resulted from lack of information of the patient and the reference of other more distant services. This may also account for the large number of patients who had already undergone some treatment, either clinical or surgical, which in turn may explain the large number of patients who did not have material collected for culture when getting to the our service, or who presented a negative result of culture. Among the positive cultures, there was a predominance of gram positive microorganisms, as in other studies ${ }^{1,2,4,6}$. The delay in the diagnosis and appropriate treatment can also justify the long hospitalization and the poor visual outcome found in our study.

The large number of cases of postoperative infection observed may have resulted from more complicated surgeries, due to the learning curve of surgeons in a teaching hospital, as well as inadequate preoperative preparation of the patients, since they were found referred in most cases from other services. In order to reduce this number, it is essential to identify and control the preoperative risk factors, institute appropriate antibiotic prophylaxis and maintain the appropriate postoperative followup. During surgery, care for the integrity of the incision preventing influx of microorganisms is a crucial factor in preventing endophthalmitis ${ }^{11}$.

The lack of correlation between variables (low statistical significance found) probably resulted from the small number of patients included in this sample. This draws attention to the need for further studies, and also of a better filling of the medical records.

\section{Conclusion}

Because it is a serious disease, the patient orientation regarding the main signs and symptoms of endophthalmitis, its early diagnosis and proper medical management are key to improve the visual prognosis of the patient, guaranteeing their quality of life and later socioeconomic integration.

\section{ReferenCES}

1. Bispo PJ, Höfling-Lima AL, Pignatari AC. [Molecular biology applied to thelaboratory diagnosis of bacterial endophthalmitis]. Arq Bras Oftalmol. 2009;72(5):734-40. Review. Portuguese.

2. Schirmbeck T, Romão E, Rodrigues ML, Figueiredo JF. [Endophthalmitis: an analysis of 58 cases]. Arq Bras Oftalmol. 2000;63(1):39-44. Portuguese.

3. Bispo PJ, Melo GB, d'Azevedo PA, Hõfling-Lima AL, Yu MC, Pignatari AC. [Culture proven bacterial endophthalmitis: a 6year review].Arq Bras Oftalmol. 2008;71(5):617-22. Portuguese.

4. Kresloff MS, Castellarin AA, Zarbin MA. Endophthalmitis. Surv Ophthalmol. 1998;43(3):193-224. Review.

5. Adan CB, Blay D, Yu MC, Freitas D, Allemann N. [Ultrasound findings in clinical suspected of endophthalmitis]. Arq Bras Oftalmol. 2001;64(5):423-8. Portuguese.

6. Melo GB, Bispo PJ, Regatieri CV, Yu MC, Pignatari AC, HöflingLima AL.Incidence of endophthalmitis after cataract surgery (2002-2008) at a Brazilianuniversity-hospital. Arq Bras Oftalmol. 2010;73(6):505-7. Portuguese.

7. Norregaard JC, Thoning H, Bernth-Petersen P, Andersen TF, Javitt JC, Anderson GF. Risk of endophthalmitis after cataract extraction: results from theInternational Cataract Surgery Outcomes study. Br J Ophthalmol. 1997;81(2):102-6.

8. Duch-Samper AM, Menezo JL, Hurtado-Sarrió M. Endophthalmitis followingpenetrating eye injuries. Acta Ophthalmol Scand. 1997;75(1):104-6.

9. Bohigian GM, Olk RJ. Factors associated with a poor visual result inendophthalmitis. Am J Ophthalmol. 1986;101(3):332-41.

10. Chaib AR, Freitas D, Scarpi MJ, Guidugli T. [Laboratory findings in endophthalmitis]. Arq Bras Oftalmol. 1997;60(3):250-7. Portuguese.

11. KashiwabuchiI FK, Khan YA, Rodrigues Jr MW, Wang J, McDonnell PJ, Daoud YJ. [Efficacy of three different methods for side port incision wound sealing]. Rev Bras Oftalmol. 2013;72(6):379-82. Portuguese.

\section{Correspondending author:}

Letícia Maria Coelho

Av. Alfredo Balena, 190 - room 3005 - Santa Efigênia

neighborhood - Belo Horizonte, MG, Brazil

ZIP code: 30130-100.

E-mail: leticiamariacoelho@yahoo.com.br 